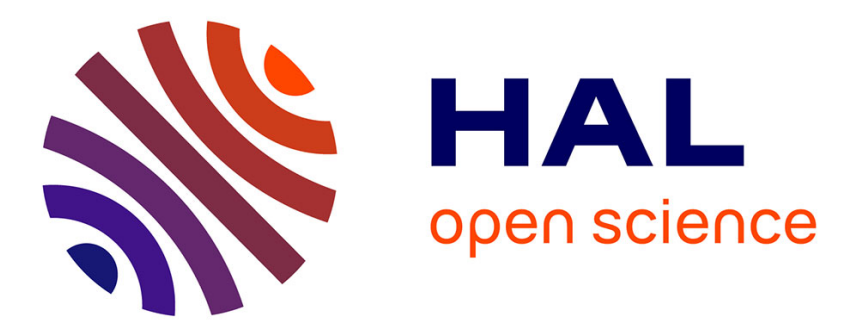

\title{
Effects of Transport Infrastructure in the Economic Development
}

José Luz, João Reis, Fábio De Araújo Leite, Karmem Araújo, Gorthon Moritz

\section{To cite this version:}

José Luz, João Reis, Fábio De Araújo Leite, Karmem Araújo, Gorthon Moritz. Effects of Transport Infrastructure in the Economic Development. IFIP International Conference on Advances in Production Management Systems (APMS), Sep 2016, Iguassu Falls, Brazil. pp.633-640, 10.1007/9783-319-51133-7_75. hal-01615746

\author{
HAL Id: hal-01615746 \\ https://hal.inria.fr/hal-01615746
}

Submitted on 12 Oct 2017

HAL is a multi-disciplinary open access archive for the deposit and dissemination of scientific research documents, whether they are published or not. The documents may come from teaching and research institutions in France or abroad, or from public or private research centers.
L'archive ouverte pluridisciplinaire HAL, est destinée au dépôt et à la diffusion de documents scientifiques de niveau recherche, publiés ou non, émanant des établissements d'enseignement et de recherche français ou étrangers, des laboratoires publics ou privés.

\section{(c)(1)}

Distributed under a Creative Commons Attribution| 4.0 International License 


\title{
Effects of Transport Infrastructure in the Economic Development
}

\author{
José Alberto Alencar Luz ${ }^{1,2}$, João Gilberto Mendes dos Reis ${ }^{1}$, Fábio de \\ Araújo Leite ${ }^{1,2}$, Karmem Weruska Fortes de Araújo ${ }^{1,2}$, and Gorthon Moritz ${ }^{1,2}$ \\ 1 Paulista University, São Paulo, Brazil \\ 2 Faculdade Santo Agostinho, Teresina, Brazil \\ josealberto@socimol.com.br; betomendesreis@msn.com
}

\begin{abstract}
This paper investigates the relationship between transport infrastructure and economic development. The analysis considers a sample of the ten countries with the highest Gross Domestic Product (GDP) among to 2010 to 2014. The GDP is correlated to the Logistic Performance Index of the World Bank (LPI) using linear regression. The results showed that there is not a relationship between the two variables, but suggest that this relationship is positive when considering the GDP per capita of the ten countries surveyed.
\end{abstract}

Keywords: Logistics Infrastructure, LPI, GDP, Linear Regression.

\section{Introduction}

Previous work has mentioned a relationship between transport infrastructure and economic development of a country or region [1]. Transportation is economically and socially vital for the countries and the result of their investments has impacts in the following decades [2]. In addition, transportation is a critical ingredient in the economic development supporting this growth and also important for the well-being of the population [3]. However, it is necessary to understand the extent of this relationship and what economic development factors are associated with transport infrastructure.

There are several factors that can discuss of economic development, among which the Gross Domestic Product (GDP), the Human Development Index, and the Distribution of Income. It is important to mention that, transport infrastructure is associated with the extent of various types of network, its usability, and quality.

Morais Aragon was the first one that pointed that the investments in the urban transport sector in Brazil generate economic growth, but he did not make a quantitative approach, which makes it impossible to a study to confirm the empirical analysis [4]. Bertussi and Ellery Junior investigated the results of public spending on transport in Brazil between 1986 and 2007. The results showed that public investment in transport causes positive effect and it is statistically significant on the economic performance of the Brazilian states [5]. 
Despite this evidence, it wonders whether countries and regions that have better transportation infrastructure are related to a higher gross domestic product. Generally, the GDP has been used to establish the percentage of investments in the country's transport. Thus, the percentage that countries have invested in transport between 1995 and 2009 has been an average of $1 \%$ per year [2]. Whereas GDP varies depending on the country's wealth, it can be assumed that the economically richest countries invest more in transport and therefore have a better infrastructure that influences in trade. This creates a circle that shows the gap between rich and poor countries.

This work seeks to answer this research gap, in other words, if there is a direct influence of the transportation infrastructure and the country's GDP. Thus, the purpose of this article is to assess the importance of transport infrastructure in relation to GDP for the ten largest economies and position Brazil in this scope. To conduct this study it was established a comparison of transport infrastructure in relation to GDP using a linear regression model.

\section{Theorethical Background}

The GDP is the value of all production of goods and services occurred in a particular place and it can be measured within the country's borders, in a state, county or region, in certain period [6]. It is considered by most researchers of the economy as the main indicator of the wealth of a country and covers three main groups of activities: agriculture, industry and services. The importance of GDP is based on the fact that there are standards it should be calculated, allowing comparisons between study sites. It is an indicator widespread and applied in various analyzes, being one of the main ways to measure the level of development and economy of certain locations.

It is important to highlight that the infrastructure of a region promotes quality of life for residents, as it induces physical interaction of locations, enabling a good performance of the flow of people, goods, and conveyances. Rostow et al. in his theory of stages of development, advocated that any growth impulse "has been preceded, almost without exception, by a substantial accumulation of investments in transport and other public works [7].

In this reasoning, the authors go on to assert that "the most important functions of these investments have been, therefore, reduce transport costs, enable an efficient combination of resources, expand the domestic market and make possible an effective conduct of international trade" [7].

Rozas and Sánche's work provides an excellent summary of the main empirical studies in this respect of possible economic development relationship with the infrastructure [8]. According to the authors, the first measurements date back to Aschauer's study in the 90s, which measured the impact on the product at the national level in the United States, investment in public works and improvement of related services during the period of 1945-1985. Overall, the author found an elasticity of investment to the growth of 0.39 , meaning an increase of $10 \%$ in infrastructure investments would allow an increase of $3.9 \%$ in the domestic 
product $[8,9]$. These estimates seem quite high, resulting in a broad debate about them, especially in the econometric field, since apparently, there were problems of definition and omitted variable and endogeneity. However, numerous studies with different methods and specifications found the positive relationship between infrastructure and growth.

More recent studies, such as Liu Yu ones, made for a Chinese economy, corroborate this positive relationship between infrastructure investment and economic growth. [10]. In effect, the author found that for the period of 1978-2009, investment in public infrastructure was a "long-term unidirectional positive impact, in the aggregate product" [10]. The elasticity found by Liu Yu, for the case of China, was 0.24 , meaning that a $10 \%$ increase in investment in infrastructure would leverage the product in $2.4 \%$ [10].

For the specific case of Brazil, the work of Araujo Junior found that infrastructure investments are positively related to economic growth, especially in the long term [1]. In the short term there is also a positive influence, by means of aggregate demand, but to a lesser extent than that achieved in the long run. In their latest work Bertussi and Ellery measured the impact of public spending in transportation in the Brazilian states of the growth rate for the period of 19862007, finding a positive and statistically significant effect, realizing a positive contribution to reducing income inequalities between them [5].

Regarding the economic aspect Mallon [11] states that the existence of a transport system is one of the essential differences of subsistence system to a market economy, as it provides an economic integration at various levels. That is, without an adequate transportation system, you cannot have a market economy, hence the importance of studying and understanding the content.

Already Aschauer considered the pioneer in the study of the effect of transport infrastructure on economic growth, says that although there was always consensus among economists that a well-developed transportation infrastructure benefits from economic growth, so far, there are no studies that prove this premise in practice [9].

In this sense, Banister and Berechman [12] emphasize that investments in transport infrastructure provide long-term economic development and states that, while necessary to generate economic growth, it is not enough.

\section{Methodology}

This article aims to investigate the possible relationship between transport infrastructure and economic development, in this case, linked to GDP. For GDP we used the values for the ten largest economies in the period between 20102014, according to Table 1. This research develops simulation considering two situations. The first relating the conventional GDP with LPI and the second GDP per capita with the same LPI.

For transport infrastructure reference was chosen the logistics performance index (LPI) established by research conducted by The Word Bank, the reference 
Table 1. GDP growth of the ten largest economies in the years 2010-2014

\begin{tabular}{lccccc}
\hline & \multicolumn{5}{c}{ GDP (billion dollars) } \\
\hline Country & 2010 & 2011 & 2012 & 2013 & 2014 \\
USA & 15,060 & 15,060 & 16,163 & 16,768 & 17,416 \\
China & 5,815 & 6,989 & 8,461 & 9,469 & 10,355 \\
Japan & 5,458 & 5,855 & 5,954 & 4,898 & 4,769 \\
Germany & 3.391 & 3,629 & 3,539 & 3,635 & 3,820 \\
France & 2,671 & 2,808 & 2,681 & 2,807 & 2,902 \\
RU & 2,137 & 2,481 & 2,630 & 2,523 & 2,847 \\
Brazil & 2,350 & 2,518 & 2,413 & 2,246 & 2,244 \\
Italy & 2,060 & 2,246 & 2,074 & 2,071 & 2,129 \\
Rússia & 1,479 & 1,791 & 2,016 & 2,096 & 2,057 \\
India & 1,727 & 1,843 & 1,831 & 1,876 & 2,047 \\
\hline
\end{tabular}

year 2014 [13]. This survey refers to an international score using six key dimensions for logistics performance of countries. The scorecard allows comparisons with the world (with the option to display the best performance of the world) on the six indicators and the overall index LPI. The logistics performance is the weighted average of the scores of countries on six dimensions. The used index of the six indicators is only the transport infrastructure. The data used in the ranking comes from a survey of logistics professionals, where questions are asked about the foreign countries in which they operate. The LPI represents respectively each country as Table 2 .

Table 2. Indicator of transport infrastructure performance

\begin{tabular}{ll}
\hline Countries & LPI \\
\hline USA & 4.18 \\
China & 3.67 \\
Japan & 4.16 \\
Germany & 4.32 \\
France & 3.98 \\
UK & 4.16 \\
Brazil & 2.93 \\
Italy & 3.78 \\
Russia & 2.59 \\
India & 2.88 \\
\hline
\end{tabular}

The sources used to collect data were from The Word Factbook [14], Word Economic Outlook Database [15], National Transport Confederation (CNT) [16], Brazilian Institute of Geography and Statistics (IBGE) [17], and Logistics Performance Index [13]. 
Data were analyzed using Microsoft Excel software (C)v. 13. A linear regression was used to verify the correlation between GDP and LPI variables, the first considered the dependent variable and the second variable the self-contained.

\section{Results}

To understand the research question in the first place we developed an average of the conventional GDPs between 2010 and 2014. From the result of this average, we related it to the LPI index for each country as can be seen in Figure 1.

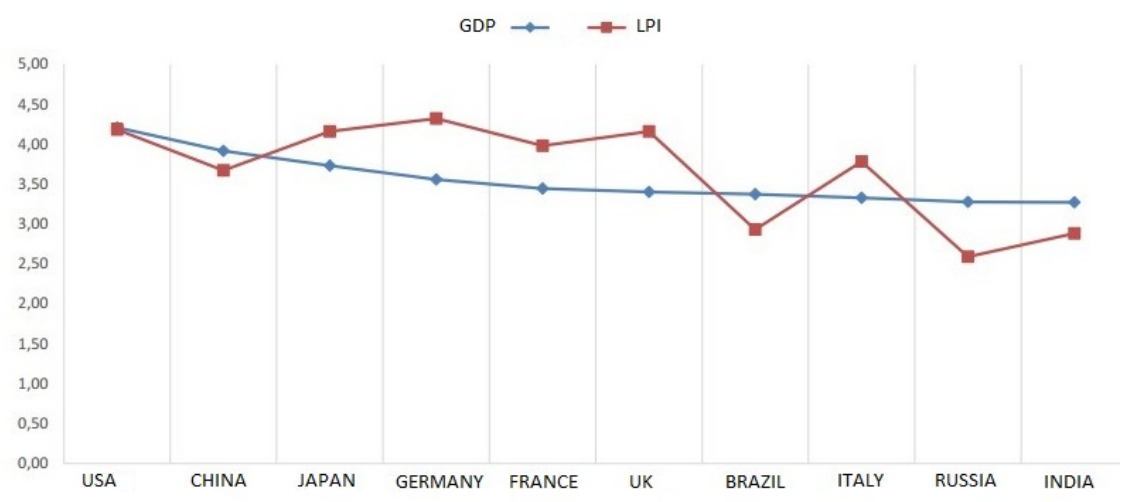

Fig. 1. GDP versus LPI

We conclude that although the LPI is different among the ten largest economies in the world, the GDP value of countries remained largely stable over this period, suggesting no influence of the performance of economic countries, which somehow contrasts the results presented by World Bank [13].

Using data collected from the survey, we seek to validate or not the highlighted conclusions and it was considered the following equation.

$$
\operatorname{Ln}(G D P)=\alpha-\beta L P I
$$

Where $\operatorname{Ln}(G D P)$ we take the logarithms of GDP and LPI refers to Logistics Performance Index of the World Bank.

It was chosen to extract the logarithm of GDP to achieve a normal linear equation and to use Orderary Linear Squares (OLS) for verification of the hypothesis. This is a technique used in Econometrics to reduce the size of the number and Facilitate comparison in the ordinary linear squares $[18,19]$. The regression results are presented in Table 3.

According to Crespo the analysis of colinearity correlation is in the trial of $\mathrm{R}$ - SQUARE where if $0.3 \geq r<0.6$, there is a relatively weak correlation between variables and $0>r<0.3$, the relationship is very weak so, it was not possible to 
Table 3. Regression Result

\begin{tabular}{cc}
\hline \multicolumn{2}{c}{ Statistical Regression } \\
\hline R MULTIPLE & $\mathbf{6 3 , 9 1 \%}$ \\
R-SQUARE & $\mathbf{4 0 , 8 5 \%}$ \\
R-SQUARE SET & 0,383 \\
ERROR STANDARD & 0,47653 \\
SAMPLE NUMBER & 50 \\
\hline
\end{tabular}

conclude many things about the relationship between the variables under study [20].

A confidence level of $95 \%$ was used, after the regression calculation, it can empirically demonstrate that there is a relatively weak correlation between the variables, because the regression explains only $40.85 \%$ of the cases. Thus, this study failed to establish the relationship between variables. However, there has been the need to use more sample data to confirm or reject the hypothesis. The data analyzed are limited to the years of 2010-2014, so it is not possible to generalize that in a wider range of GDP continues to be a relatively weak correlation.

However, when analyzing the correlation between GDP per capita and the LPI, it shows a high correlation between variables (0.722). Analyzing the LPI and $L n G D P$ per capita of the countries, as shown in Figure 2.

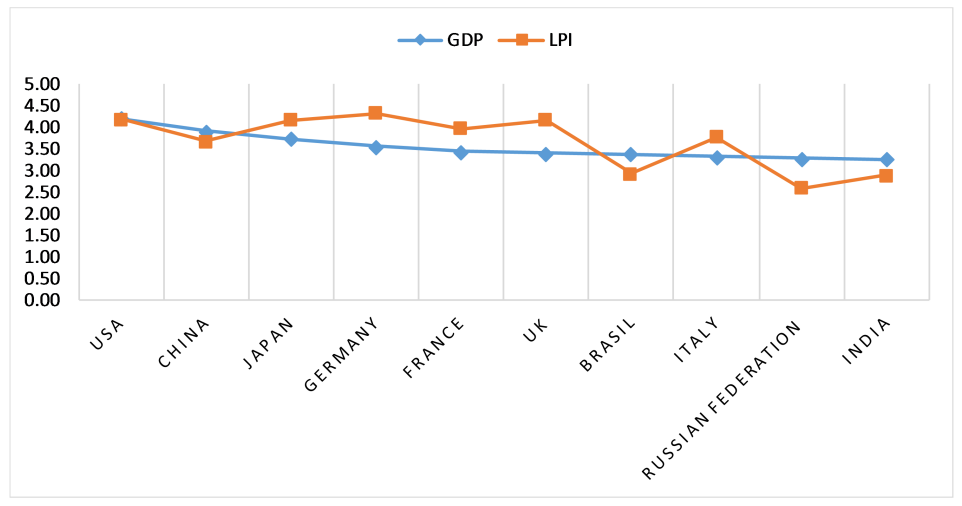

Fig. 2. LPI versus GDP per Capita

With the exception of India, the countries with higher GDP per capita have a higher index of the average LPI, which considers the World Bank surveys in 2007, 2010, 2012 and 2014. 
To check whether there would be significant change in the regression model, it was remade linear regression considering the GDP per capita and the result is shown in Table 4.

Table 4. Regression Result

\begin{tabular}{cc}
\hline \multicolumn{2}{c}{ Statistical Regression } \\
\hline R MULTIPLE & $\mathbf{7 2 , 2 2 \%}$ \\
R-SQUARE & $\mathbf{5 2 , 1 0 \%}$ \\
R-SQUARE SET & 0,461 \\
ERROR STANDARD & 0,83369 \\
SAMPLE NUMBER & 10 \\
\hline
\end{tabular}

The model fits better with $\mathrm{R}$ Multiple value above 0.7 and regression explaining $52.1 \%$ of cases. Of course it is necessary to considerer the smaller sample size, and although there is more adhesion, it would not be possible to conclude that the LPI directly influences GDP.

\section{Conclusions}

This paper aims to highlight the relationship between logistics performance index of the ten largest economies in the world in relation to GDP. After the development of a linear regression model it is concluded that there is no relationship between the LPI and GDP for countries in the selected sample. However, a second analysis suggests that this relationship exists between LPI and the GDP per capita, with a strong correlation between the following variables (0.722).

The next step of this research would be searching for more data to confirm or refute the hypothesis that the LPI is related to GDP per capita. In addition, it intends to verify whether this relationship can be assigned regionally, in the specific case considering the Brazilian states by developing an equivalent regional index to LPI.

\section{References}

1. Araújo Júnior, I.T.d.A.: Investimentos em Infra-estrutura e Crescimento Econômico no Brasil. Revista Economia e Desenvolvimento 5(2), 161-188 (2006)

2. OECD/ITF: Spending on Transport Infrastructure 1995-2011. Tech. rep. (2013)

3. OECD/ITF: Understanding the Value of Transport Infrastructure. Tech. rep. (2013)

4. Morais, A., Aragão, J.: Gasto Público em Infraestrutura de Transporte é Produtivo. In: XVI Congresso Brasileiro de Transporte e Trânsito. ANTP, Maceio (2007)

5. Bertussi, G.L., Ellery Junior, R.: Infraestrutura de Transporte e Crescimento Econômico no Brasil. Journal of Transport Literature 6(4), 101-132 (2012) 
6. Gay, A.L., Kohler, R.: Projeto de Teste de Correlação entre o Vab Serviços e o Vab Total de Municípios do Rio Grande do Sul no Periodo 1999-2012. Salão do Conhecimento 1(1), 1-5 (2015)

7. Rostow, W., Baker Jr, R., Rex, G.: The Economics of Take-Off into Sustained Growth. Palgrave Macmillan, London (1963)

8. Rozas, P., Sánchez, R.: Desarrollo de Infraestructura y Crecimiento Económico: Revisión Conceptual. Naciones Unidas, CEPAL, División de Recursos Naturales e Infraestructura, Santiago (2004)

9. Aschauer, D.: Is Public Expenditure Productive? Journal of Monetary Economics 23(2), 177-200 (1989)

10. Liu, Y.: Public Infrastructure Investment and Economic Growth in China: An Empirical Analysis Using VAR. Tese Economy, University of Ottawa, Ontario (2011)

11. Mallon, R.: Transport and Economic Development. Economic Digest Summer(1), 8-13 (1960)

12. Banister, D., Berechman, J.: Transport and Economic Development. UCL, Santiago (2000)

13. Arvis, J.F., Saslavsky, D., Ojala, L., Shepherd, B., Busch, C., Raj, A.: Trade Logistics in the Global Economy: The Logistics Performance Index and Its Indicators. The World Bank, Washington (2014)

14. CIA: The World Factbook (2016), https://www.cia.gov/library/publications/ the-world-factbook/

15. International Monetary Fund: World Economic Outlook Database October 2015, https://www.imf .org/external/pubs/ft/weo/2015/02/weodata/index.aspx

16. Confederação Nacional do Transporte, http://www.cnt.org.br/

17. Instituto Brasileiro de Geografia e Estatística, http://www.ibge.gov.br/home/

18. Head, K., Mayer, T.: Chapter 3 - Gravity Equations: Workhorse,Toolkit, and Cookbook. In: Gita Gopinath, E.H., Rogoff, K. (eds.) Handbook of International Economics, Handbook of International Economics, vol. 4, pp. 131-195. Elsevier (2014)

19. Bensassi, S., Márquez-Ramos, L., Martínez-Zarzoso, I., Suárez-Burguet, C.: Relationship Between Logistics Infrastructure and Trade: Evidence from Spanish Regional Exports. Transportation Research Part A: Policy and Practice 72, 47-61 (2015)

20. Crespo, A.: Estatística Fácil. Saraiva, São Paulo (2009) 